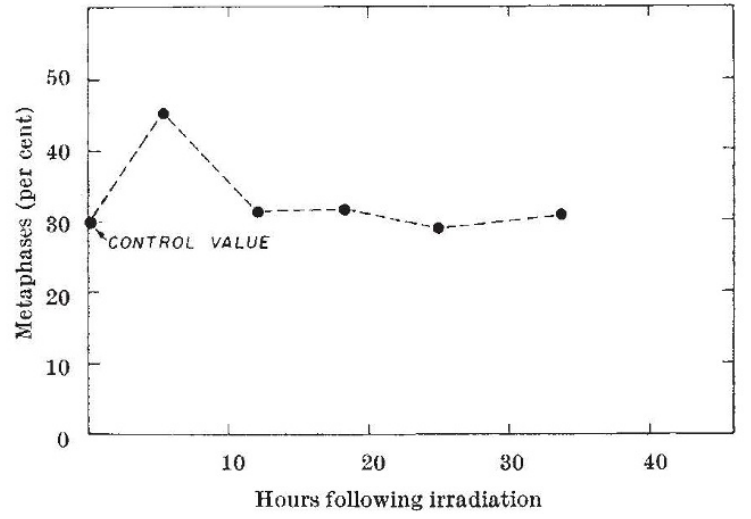

Fig. 2. The percentage of cells in mitosis in metaphase in cells glass attached for $3 \mathrm{hr}$. prior to irradiation with 451 rads. With these cells it is not possible to observe the early post-irradiation changes, due to the lag period following trypsinization, but similar studies with growing cells $\left(16 \mathrm{hr}\right.$. of attachment at $37^{\circ} \mathrm{C}$.) reveal an earlier and more pronounced semi-synchrony. The cells in the work of Elkind and Sutton (ref. 6) were similar to those shown here

tions can only be taken to indicate possible 'piling up' of cells in some sensitive phase. It is of interest that variations in lethality and variations in chromosome cycle do coincide; and this may lend support to recent hypotheses relating chromosome damage and cellular death ${ }^{1,8,9}$

\section{Nathan Mantel}

Charles L. Greenblatt

National Cancer Institute and National Institute

of Arthritis and Metabolic Diseases, National Institutes of Health Bethesda, Maryland.

Greenblatt, C. L., Intern. J. Rad. Biol. (in the press), ${ }^{2}$ Wakonig, R., and Ford, D. K., Canad. J. Zool., 38, 203 (1960).

3 Bender, M. A., and Wolff, S., Amer. Nat. (in the press).

- Sparrow, A. N., Ann. N.Y. Acad. Sci., 51, 1508 (1951).

${ }^{5}$ Giese, A. C., Quart. Rev. Biol., 22, 253 (1947).

e Elkind, M. M., and Sutton, H., Nature, 184, 1293 (1959).

' Carlson, J. G., in Radiation Biology, edit. by Hollaender, A., 1 (McG

${ }^{8}$ Puck, T. T., Amer. Nat., 94, 95 (1960); Proc. U.S. Nat. Acad. Sci., 44, 772 (1958).

'Engelbcrg, J., Rad. Res., 9, 441 (1959).

\section{Retention of Labelled Phosphate in Normal Chicks on Different Feeds and in Normal and Hormonally Caponized Cockerels}

Is an earlier communication ${ }^{1}$ some experimonts on the phosphate metabolism of growing chicks were described. Since then the material has been extended and procedures modified.

In 13 series pedigree hatched chicks (males or both sexes) were intravenously injected when 20-113 days old with 8-48 $\mu \mathrm{c}$. of orthophosphate labelled with phosphorus-32.

The animals were killed at suitable intervals from immediately to eleven weeks after injection. Cortain easily preparable whole bones wore taken from each chick, dried, ashed and dissolved in hydrochloric acid. Radioactivity was measured on aliquots from the solutions. In one series whole-body preparations were made and radioactivity was measured on aliquots of ash dissolved in nitric acid.

When treated as given in the headings (1-3) the following results wore obtained:

(1) When kept on the same feed. (a) Male chicks retained more labelled phosphate than did the females. (b) Within sexes the ratio bone-weight/ body-weight showed a positive correlation with the retention. This may explain the difference between sexes, as cocks in general have a larger quotient than hens. (c) The maximal retention-level in bone was not reached until about two weeks after injection. (d) The biological half life-time $\left(t_{\frac{1}{2}}\right)$ was shorter for tibiæ than for metatarsalæ. (e) In general, the relative maximal retention in the skeleton diminishes with increasing age.

(2) When given different feeds (after maximum retention had been reached). (a) Increasing both calcium and phosphate or only phosphate in an other. wise unaltered diet shortened $t_{\frac{1}{2}}$ in bones and in the body as a whole. Consequently $t_{1}$ is not a constant but depends to a great extent on nutritional conditions. (b) Increasing only calcium prolonged $t_{\frac{1}{1}}$, probably by decreasing phosphate resorption from the foed.

(3) Stilboestrol caponized cockerels. (a) Compared with their untreated whole brothers, animals caponized and then injected showed less retention in skeleton and higher activity in blood plasma. (b) In animals injected and then caponized the disappearance of labelled phosphate was accelerated.

This work was supported by grants from the Swedish Agricultural Research Council.

\section{S. A. Svensson}

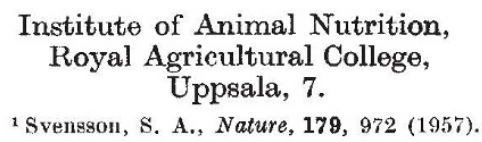

\section{Occurrence of Bismuth-207 at Eniwetok Atoll}

DURING March 18-30, 1961, 308 samples of soil, water, algae, land plants, plankton, fish and invertebrates were collected at Eniwetok Atoll for assay of radioactivity. Two of the samples, taken from the bottom of the lagoon, contained a $\gamma$-emitting isotope not previously reported at the Eniwetok Test Site. One sample, which consisted primarily of radiolarians, foraminiferans, and small sand grains, was collected in a plankton net placed under the outflow of a salt water supply system for marine aquaria in which the intake pipe was located on the bottom of the lagoon near Eniwetok Island. The other sample was a specimen of a brown alga, Dictyota divaricata Lamouroux, collected in threc feet of water in the lagoon off Glenn Island on the west side of the atoll.

The algal sample (wet weight $63 \mathrm{gm}$.) was dried, dry-ashed at $500^{\circ} \mathrm{C}$. for $20 \mathrm{hr}$. (ash-weight $10 \cdot 6 \mathrm{gm}$.), dissolved in $500 \mathrm{ml}$. of $12 \mathrm{~N}$ hydrochloric acid to which $20 \mathrm{mgm}$. of bismuth earrier had been added, and boiled to dryness. The $\gamma$-spectrum of the residue as determined by the use of a 3 -in. by 3 -in. sodium iodide (thallium) crystal connected to a 256-shannel analyser contained the photopeaks of cobalt-57, cobalt-60, zinc-65, manganese-54 and ruthenium-106 -rhodium-106. In addition, photopeaks with energies of $0.088,0.57,1.064$ and 1.77 were present. The latter correspond to the photopeaks of bismuth207, an isotope with a physical half-life of eight years. The presence of bismuth-207 in the algal sample was verified by the following methods.

The ash, which had been treated with hydrochloric acid and dried, was dissolved in $50 \mathrm{ml}$. of $6 \mathrm{~N}$ hydro- 